\title{
Syntheses of Metal Complexes of Selenocysteamine
}

\author{
Hiromu Sakurai, Akira Yokoyama and Hisashi Tanaka \\ Faculty of Pharmaceutical Sciencies, Kyoto University $\mathbf{1}^{\mathbf{1}}$
}

(Received October 15, 1970)

We have studied the complex formation of selenocysteamine with metal ions and reported that selenocysteamine is mainly present as the zwitterionic form in the wide range of $\mathrm{pH}^{2)}$ and the cationoid metal complexes rather than the chelate were preferably produced under general condition. ${ }^{3}$ ) These properties in complex formation are considerably different from those of cysteamine. In order to discuss the complex formation of selenocysteamine further, we synthesized some metal complexes by the application of the methods reported by Jicha and Busch") and Foye ${ }^{5)}$ for the syntheses of the metal complexes of cysteamine. The metal complexes synthesized are listed in Table I together with the complexes reported previously. ${ }^{3,6)}$

TABLE I. Metal Complexes of Selenocysteamine

\begin{tabular}{|c|c|c|c|c|c|c|c|c|c|}
\hline \multirow{3}{*}{$\begin{array}{l}\text { Metal } \\
\text { ion }\end{array}$} & \multirow{3}{*}{ Structure } & \multirow{3}{*}{ Formula } & \multirow{3}{*}{ Color } & \multicolumn{6}{|c|}{ Analysis (\%) } \\
\hline & & & & \multicolumn{3}{|c|}{ Calcd. } & \multicolumn{3}{|c|}{ Found } \\
\hline & & & & $\mathrm{C}$ & $\mathrm{H}$ & $\mathbf{N}$ & $\mathrm{C}$ & $\mathrm{H}$ & $\mathrm{N}$ \\
\hline \multirow[t]{4}{*}{$\mathrm{Ni}(\mathrm{II})$} & $\begin{array}{l}\left(\mathrm{H}_{3} \mathrm{~N}^{+} \mathrm{CH}_{2} \mathrm{CH}_{2} \mathrm{Se}\right)_{2^{-}} \\
\left.\mathrm{NiCl}_{2}^{-} \cdot 2 \mathrm{H}_{2} \mathrm{O}^{\alpha}\right)\end{array}$ & $\mathrm{C}_{4} \mathrm{H}_{18} \mathrm{O}_{2} \mathrm{~N}_{2} \mathrm{NiSe}_{2} \mathrm{Cl}_{2}$ & red purple & 12.00 & 4.67 & & 11.61 & 4.39 & \\
\hline & $\begin{array}{l}\left(\mathrm{H}_{3} \mathrm{~N}^{+} \mathrm{CH}_{2} \mathrm{CH}_{2} \mathrm{Se}\right)_{2-} \\
\left.\mathrm{NiSO}_{4}^{2-} \cdot 2 \mathrm{H}_{2} \mathrm{O}^{a}\right)\end{array}$ & $\mathrm{C}_{4} \mathrm{H}_{18} \mathrm{O}_{6} \mathrm{~N}_{2} \mathrm{SNiSe}$ & red purple & 10.37 & 4.25 & & 10.94 & 4.14 & \\
\hline & $\left(\mathrm{NH}_{2} \mathrm{CH}_{2} \mathrm{CH}_{2} \mathrm{Se}\right)_{2} \mathrm{Ni}$ & $\mathrm{C}_{4} \mathrm{H}_{12} \mathrm{~N}_{2} \mathrm{NiSe}_{2}$ & pale yellow & 15.76 & 3.98 & 9.19 & 15.72 & 4.08 & 8.99 \\
\hline & $\begin{array}{l}{\left[\left(\mathrm{NH}_{2} \mathrm{CH}_{2} \mathrm{CH}_{2} \mathrm{Se}\right)_{2}-\right.} \\
\mathrm{Ni}]_{2} \mathrm{NiCl}_{2}\end{array}$ & $\mathrm{C}_{8} \mathrm{H}_{24} \mathrm{~N}_{4} \mathrm{Ni}_{3} \mathrm{Se}_{4} \mathrm{Cl}_{2}$ & $\begin{array}{l}\text { greenish } \\
\text { brown }\end{array}$ & 13.00 & 3.28 & 7.58 & 12.78 & 3.94 & 7.34 \\
\hline $\operatorname{Pd}(\mathrm{II})$ & $\begin{array}{l}{\left[\left(\mathrm{NH}_{2} \mathrm{CH}_{2} \mathrm{CH}_{2} \mathrm{Se}\right)_{2}-\right.} \\
\mathrm{Pd}]_{2} \mathrm{PdCl}_{2}\end{array}$ & $\mathrm{C}_{8} \mathrm{H}_{24} \mathrm{~N}_{4} \mathrm{Pd}_{3} \mathrm{Se}_{4} \mathrm{Cl}_{2}$ & orange & 10.89 & 2.75 & 6.35 & 10.79 & 3.42 & 6.03 \\
\hline \multirow{4}{*}{$\begin{array}{l}\mathrm{Pt}(\mathrm{II}) \\
\mathrm{Co}(\mathrm{II})\end{array}$} & $\left(\mathrm{NH}_{2} \mathrm{CH}_{2} \mathrm{CH}_{2} \mathrm{Se}\right)_{2} \mathrm{Pt}$ & $\mathrm{C}_{4} \mathrm{H}_{12} \mathrm{~N}_{2} \mathrm{PtSe}_{2}$ & yellow & 10.89 & 2.75 & 6.35 & 11.09 & 2.69 & 6.13 \\
\hline & $\begin{array}{l}\left(\mathrm{H}_{3} \mathrm{~N}^{+} \mathrm{CH}_{2} \mathrm{CH}_{2} \mathrm{Se}\right)_{3}^{-} \\
\mathrm{CoCl}_{3}^{-} \cdot \mathrm{H}_{2} \mathrm{O}\end{array}$ & $\mathrm{C}_{6} \mathrm{H}_{23} \mathrm{ON}_{3} \mathrm{CoSe}_{3} \mathrm{Cl}_{3}$ & red purple & 12.97 & 4.18 & & 13.42 & 4.24 & \\
\hline & $\left(\mathrm{NH}_{2} \mathrm{CH}_{2} \mathrm{CH}_{2} \mathrm{Se}\right)_{3} \mathrm{Co}$ & $\mathrm{C}_{6} \mathrm{H}_{18} \mathrm{~N}_{3} \mathrm{CoSe}_{3}$ & green & 16.83 & 4.25 & 9.82 & 16.67 & 4.45 & 9.99 \\
\hline & $\begin{array}{l}{\left[\left(\mathrm{NH}_{2} \mathrm{CH}_{2} \mathrm{CH}_{2} \mathrm{Se}\right)_{2}-\right.} \\
\mathrm{Co}]_{2} \mathrm{CoCl}_{2}\end{array}$ & $\mathrm{C}_{8} \mathrm{H}_{24} \mathrm{~N}_{4} \mathrm{Co}_{3} \mathrm{Se}_{4} \mathrm{Cl}_{2}$ & dark green & 13.00 & 3.28 & 7.57 & 13.07 & 3.79 & 7.58 \\
\hline \multirow[t]{2}{*}{$\mathrm{Cu}(\mathrm{II})$} & $\begin{array}{l}\left(\mathrm{NH}_{2} \mathrm{CH}_{2} \mathrm{CH}_{2} \mathrm{Se}\right)- \\
\mathrm{CuCl}^{b)}\end{array}$ & $\mathrm{C}_{2} \mathrm{H}_{6} \mathrm{NCuSeCl}$ & yellow & 10.82 & 2.73 & 6.31 & 10.66 & 3.23 & 5.94 \\
\hline & $\begin{array}{l}{\left[\left(\mathrm{NH}_{2} \mathrm{CH}_{2} \mathrm{CH}_{2} \mathrm{Se}\right)-\right.} \\
\mathrm{Cu}]_{2} \mathrm{CuCl}_{4}{ }^{b)}\end{array}$ & $\mathrm{C}_{4} \mathrm{H}_{12} \mathrm{~N}_{2} \mathrm{Cu}_{3} \mathrm{Se}_{2} \mathrm{Cl}_{4}$ & dark gray & 8.30 & 2.10 & 4.84 & 8.70 & 2.76 & 4.90 \\
\hline $\mathrm{Zn}(\mathrm{II})$ & $\begin{array}{l}\left(\mathrm{NH}_{2} \mathrm{CH}_{2} \mathrm{CH}_{2} \mathrm{Se}\right)- \\
\mathrm{Zn} \cdot \mathrm{OH}\end{array}$ & $\mathrm{C}_{2} \mathrm{H}_{7} \mathrm{ONSeZn}$ & white & 10.89 & 3.19 & 6.33 & 12.45 & 3.31 & 6.85 \\
\hline
\end{tabular}

a) from reference 3 )

b) from reference 6)

1) Location: Yoshida Shimoadachi-cho, Sakyo-ku, Kyoto.

2) H. Tanaka, H. Sakurai, and A. Yokoyama, Chem. Pharm. Bull. (Tokyo), 18, 1015 (1970).

3) A. Yokoyama, H. Sakurai, and H. Tanaka, Chem. Pharm. Bull. (Tokyo), 18, 1021 (1970).

4) D.C. Jicha and D.H. Busch, Inorg. Chem., 1, 872 (1962).

5) W.O. Foye and J. Mickles, J. Pharm. Sci., 53, 1030 (1964).

6) H. Sakurai, A. Yokoyama, and H. Tanaka, Chem. Pharm. Bull. (Tokyo), 18, 2373 (1970). 
In the reaction of selenocysteamine with nickel ion, chelate and polynuclear complex were obtained. Thus, three types of the complex were obtained including the cationoid complex reported previously.3) Similarly, three types of complex were obtained in the reaction with cobalt (II) ion. In the chelate and the cationoid complex, cobalt is considered to be present in tervalent state, whereas in the polynuclear complex the valence state of cobalt is considered to be bivalent from the results of the elemental analyses.

From selenocysteamine and palladium chloride, polynuclear complex of the similar type to polynuclear nickel complex was obtained. On the other hand, from selenocysteamine and potassium tetrachloroplatinate, a chelate with ligand-to-metal ratio of $2: 1$ was obtained. While in the case of cysteamine, similar chelate was obtained with potassium tetrachloropalladate.4) From selenocysteamine and zinc oxide, a chelate was obtained.

The structures of the metal complexes of cysteamine were presumed as chelate, cationoid complex, or polynuclear complex by the results of the elemental analyses and the magnetic moment measurement.4,5) The metal complexes of selenocysteamine described here are synthesized similarly to the cases of the metal complexes of cysteamine and considered to have the similar structure to the complexes of cysteamine from the results of the elemental analyses. In Table I, the structures of the complexes of selenocysteamine are shown, according to those for the complexes of cysteamine reported by Jicha and Busch ${ }^{4)}$ and Foye. ${ }^{5)}$ In the polynuclear complexes, structure involving selenium bridge is considered as in the cases of cysteamine metal complexes. A complex obtained from zinc oxide may possibly be regarded as a chelate with ligand-to-metal ratio of $1: 1$ from the result of the elemental analysis and its structure was tentatively presumed analogously to that of zinc complex of cysteamine.5)

\section{Experimental}

Selenocysteamine hydrochloride was prepared according to the method described in the previous paper. ${ }^{2)}$

Nickel Chelate_Selenocysteamine hydrochloride $(5.1 \mathrm{~g}, 0.032 \mathrm{~mole})$ and $\mathrm{NaOH}(2.6 \mathrm{~g}, 0.065 \mathrm{~mole})$ were dissolved in $60 \mathrm{ml}$ of water. This solution was added slowly with stirring to $3.8 \mathrm{~g}$ of $\mathrm{NiCl}_{2} \cdot 6 \mathrm{H}_{2} \mathrm{O}(0.016$ mole) in $60 \mathrm{ml}$ of water with a little heating. Deep red color appeared initially faded rapidly and pale yellow crystals separated out upon finishing of the addition of the ligand. Stirring was continued for several mitutes and the crystalline solid was collected by filtration after the reaction mixture was cooled to room temperature. The crystals were washed twice with $25 \mathrm{ml}$ portions of water, followed by two $25 \mathrm{ml}$ portions of dehydrated EtOH, and dried in vacuo over $\mathrm{P}_{2} \mathrm{O}_{5}$, yield $5.92 \mathrm{~g}$.

Polynuclear Nickel Complex_- Selenocysteamine hydrochloride (1.6 g, $0.01 \mathrm{~mole})$ was dissolved in 13 $\mathrm{ml}$ of dehydrated EtOH. To this solution, $\mathrm{NaOH}(0.79 \mathrm{~g}, 0.02 \mathrm{~mole})$ in $5 \mathrm{ml}$ of $60 \%$ aqueous EtOH was added and $\mathrm{NaCl}$ formed was removed by filtration. The clear ligand solution was added slowly with stirring to $13 \mathrm{ml}$ of a warm aqueous solution containing $1.78 \mathrm{~g}(0.0075$ mole $)$ of $\mathrm{NiCl}_{2} \cdot 6 \mathrm{H}_{2} \mathrm{O}$. The color of the solution turned to deep red and greenish brown crystals separated out almost immediately. The reaction mixture was allowed to stand for approximately $2 \mathrm{hr}$ under cooling. The geenish brown plates were collected by filtration, washed three times with a little portions of cold $\mathrm{EtOH}$, and dried in vacuo over $\mathrm{P}_{2} \mathrm{O}_{5}$, yield $1.1 \mathrm{~g}$.

Polynuclear Palladium Complex_-Selenocysteamine hydrochloride (1.61 g, $0.01 \mathrm{~mole})$ and $\mathrm{NaOH}$ $(0.80 \mathrm{~g}, 0.02 \mathrm{~mole})$ were dissolved in $30 \mathrm{ml}$ of water. This solution was added slowly with stirring to $0.89 \mathrm{~g}$ of palladium chloride $(0.005 \mathrm{~mole})$ in $50 \mathrm{ml}$ of $0.1 \mathrm{~N} \mathrm{HCl}$. Orange precipitates were formed with dropping of solution of the ligand but they dissolved again when the addition of all the ligand solution was completed. Orange crystals which were precipitated by keeping the solution in a freezer overnight were collected by filtration, washed twice with $10 \mathrm{ml}$ portions of water followed by two $10 \mathrm{ml}$ portions of EtOH, and dried in vacuo over $\mathrm{P}_{2} \mathrm{O}_{5}$, yield 0.97 .

Platinum Chelate-Selenocysteamine hydrochloride $(0.77 \mathrm{~g}, 0.0048 \mathrm{~mole})$ and $\mathrm{NaOH}(0.38 \mathrm{~g}, 0.0096$ mole) were dissolved in $20 \mathrm{ml}$ of water. This solution was added slowly with stirring to $1.00 \mathrm{~g}$ potassium tetrachloroplatinate $(0.0024 \mathrm{~mole})$ in $20 \mathrm{ml}$ of warm water. The color of the resulted deep red solution quickly turned yellow, and a small quantity of yellow crystals separated out. After the reactioh mixture was allowed to stand under cooling for several hours, the product was collected by filtration and washed twice with $10 \mathrm{ml}$ portions of water, twice with a little portions of $\mathrm{EtOH}$, and dried in vacuo over $\mathrm{P}_{2} \mathrm{O}_{5}$, yield $0.77 \mathrm{~g}$.

Cationoid Cobalt Complex_-This complex was prepared by mixing selenocysteamine hydrochloride and $\mathrm{CoCl}_{2}$ in a molar ratio of 2:1 similarly to the case of the cationoid nickel complex. ${ }^{3)}$ The same complex 
was also obtained with the molar ratio of $1: 1$. From $1.60 \mathrm{~g}$ of selenocysteamine hydrochloride and $1.19 \mathrm{~g}$ of $\mathrm{CoCl}_{2} \cdot 6 \mathrm{H}_{2} \mathrm{O} 1.9 \mathrm{~g}$ of the complex was obtained.

Cobalt Chelate-Selenocysteamine hydrochloride $(1.61 \mathrm{~g}, 0.01 \mathrm{~mole})$ and $\mathrm{NaOH}(0.80 \mathrm{~g}, 0.02 \mathrm{~mole})$ were dissolved in $20 \mathrm{ml}$ of water. This solution was added slowly with stirring to $0.80 \mathrm{~g}$ of $\mathrm{CoCl}_{2} \cdot 6 \mathrm{H}_{2} \mathrm{O}$ $(0.0033 \mathrm{~mole})$ in $20 \mathrm{ml}$ of water. Color of the solution turned to green and deep green crystals separated out after stirring for $6 \mathrm{hr}$. The product was collected by filtration and washed twice with $10 \mathrm{ml}$ portions of water, twice with $10 \mathrm{ml}$ portions of $\mathrm{EtOH}$, and dried in vacuo over $\mathrm{P}_{2} \mathrm{O}_{5}$, yield $1.2 \mathrm{~g}$.

Polynuclear Cobalt Complex__ This complex was prepared almost similarly to the case of polynuclear nickel complex. From $1.60 \mathrm{~g}$ of selenocysteamine hydrochloride and $1.81 \mathrm{~g}$ of $\mathrm{CoCl}_{2} \cdot 6 \mathrm{H}_{2} \mathrm{O} 1.60 \mathrm{~g}$ of the complex was obtained by the use of dehydrated $\mathrm{MeOH}$ as the solvent in the atmosphere of $\mathrm{N}_{2}$.

Zinc Chelate_-Selenocysteamine hydrochloride $(1.6 \mathrm{~g}, 0.01 \mathrm{~mole})$ was dissolved in $6.5 \mathrm{ml}$ of water and neutralized by the addition of an aqueous solution of $\mathrm{NaOH}(0.40 \mathrm{~g}, 0.01 \mathrm{~mole})$. To this solution was added $0.81 \mathrm{~g}(0.01 \mathrm{~mole})$ of zinc oxide, and the resulted suspension was kept at $40^{\circ}$ with stirring, and $\mathrm{CS}_{2}(1 \mathrm{ml}$, 0.015 mole) was added dropwise. After the addition of $\mathrm{CS}_{2}$, the suspension was stirred for $4 \mathrm{hr}$. White solid was isolated and washed with water followed by EtOH, and dried in vacuo over $\mathrm{P}_{2} \mathrm{O}_{5}$, yield 1.5 g.

Chem. Pharm. Bull.

UDC $547.556 .33 .03: 547.962 .3 .09$

\title{
Spectral Changes of Various Dyes by Bovine Serum Albumin and by Organic Solvents1)
}

\author{
Ikuo Moriguchi, Shizuo Fushimi and Nobuyoshi Kaneniwa
}

School of Pharmaceutical Sciences, Showa University $\left.{ }^{2}\right)$

(Received September 17, 1970)

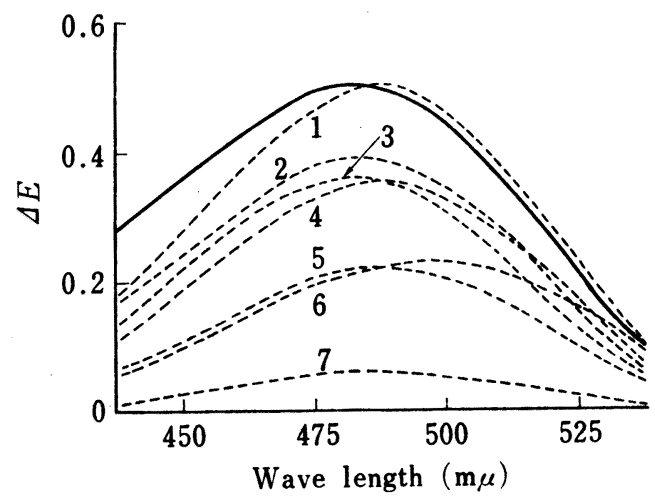

Fig. 1. Spectral Changes of HABA by BSA and by Organic Solvents at $37^{\circ}$

$$
\begin{aligned}
& \text { reference: } 5 \times 10^{-6} \mathrm{M} H A B A(\mathrm{Na} \text { salt }) \text { in water } \\
& \text { : } 5 \times 10^{-5} \mathrm{M} \text { HABA(Na salt) and } 5 \times 10^{-6} \mathrm{M} \text { BSA } \\
& \text { in } 0.1 \mathrm{M} \text { phosphate buffer of } \mathrm{pH} 7.0 \\
& 5 \times 10^{-5} \mathrm{M} \text { HABA(Na salt) in } 80 \%(\mathrm{v} / \mathrm{v}) \text { aqueous } \\
& \text { organic solvents (1: 2-propanol, 2: dioxane, 3: } \\
& \text { acetone, 4: 1-propanol, 5: ethanol, 6: hexa- } \\
& \text { methylphosphoramide, } 7 \text { : methanol) }
\end{aligned}
$$

Protein-induced changes in optical absorption of dyes ${ }^{3}$ are well known as metachromasy. In the previous paper ${ }^{1 b)}$ dealing with the mechanism of albumininduced metachromasy of monoazo dye 2-(4'-hydroxyphenylazo) benzoic acid (HA$\mathrm{BA}$ ), it has been shown that the spectral change of HABA is concerned with the polarity in the dye environment, and that the metachromasy by bovine serum albumin (BSA) can be best simulated when the dye is dissolved in high concentrations of aqueous 2-propanol. In this paper, to see if such a spectral simulation occurs with other dyes, the spectral changes of several kinds of monoazo dyes, diazo dyes, fluoresceins, and sulfonphthaleins by BSA and by organic solvents are investigated.

1) a) This forms Part VII of "Spectroscopic Studies on Molecular Interactions"; $b$ ) Part VI: I. Moriguchi, S. Fushimi, C. Ohshima, and N. Kaneniwa, Chem. Pharm. Bull. (Tokyo), 18, 2447 (1970).

2) Location: Hatanodai, Shinagawa-ku, Tokyo, 141, Japan.

3) They are reviewed in I.M. Klotz, "The Proteins," Vol. 1, ed. by H. Neurath and K. Bailey, Academic Press, 1953, p. 727; M.C. Meyer and D.E. Guttman, J. Pharm. Sci., 57, 895 (1968). 